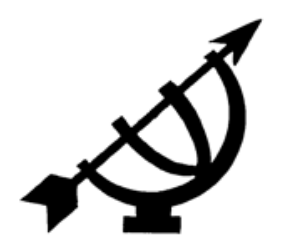

\title{
Education and the role of the church in Africa: three relevant aspects
}

\author{
C.A. Jansen, F.J. Pretorius \& E.J. van Niekerk
}

School of Arts, Education, Languages \& Communication

Department of Teacher Education

Unisa

PRETORIA

E-mail: janseca@unisa.ac.za

pretofj@unisa.ac.za

vniekej@unisa.ac.za

\begin{abstract}
Education and the role of the church in Africa: three relevant aspects

In this article an attempt is made to provide a grounded basis for expanded church involvement in the provision of formal education, HIV and AIDS education and leadership education in Africa. This is done on the basis of a fundamental reflection on the role of the church in education, as well as a brief analysis of the formal education challenge, the HIV and AIDS challenge and the leadership challenge in Africa.
\end{abstract}

\section{Opsomming}

Onderwys en die rol van die kerk in Afrika: drie relevante aspekte

In hierdie artikel word gepoog om 'n begronde regverdiging vir groter kerklike betrokkenheid in die voorsiening van formele onderwys, HIV- en VIGS-opvoeding en leierskapsopleiding in Afrika te gee. Dit word gedoen aan die hand van 'n fundamentele refleksie oor die rol van die kerk in opvoeding/ onderwys, asook 'n kort uiteensetting van die uitdagings met betrekking tot formele onderwys, HIV en VIGS en leierskap in Afrika.

\section{Introduction}

The church has historically played a significant role in African formal education (Sifuna, 1990; Maarthai, 2009:38) and is still today exert- 
ing a significant influence in education. This is not the only role that the church has played in Africa. In its submission to the Commission for Africa (2006:15), the Evangelical Christian Community in Africa in 2006 highlighted the role that the church can play in assisting development:

The church has a big role to play in bringing about social changes which in turn can enable development.

From a Christian reformational perspective one agrees with this. Eminent reformational scholars such as Herman Dooyeweerd (1963; 1968; 1979) point out that the history and development of civilisation is related to the influence and manifestation of a society's religious ground motive (see par. 4).

In order to research the role of the church in education (which necessarily impacts on development) the authors, who are educationists, initially researched the challenges related to formal education, HIV and AIDS education and leadership education in contemporary Africa. From these challenges it became clear that the role of the Christian church is becoming more important, and the increasing complexity of problematic issues in Africa implies that the church will have to rethink its role in education.

The central problem addressed in this article is: "What is the role of the church in making a contribution towards formal education, HIV and AIDS education and leadership education in Africa?" The purpose of this article is to reflect on the involvement of the church in education in Africa. This implies that not only an analysis of the African situation regarding education provision, HIV and AIDS education and leadership training should be undertaken, but that the reflection will have to include a fundamental analysis of the role of the church in education.

A literature study of the relevant issues will form the basis for the argument put forward in this article.

\section{The role of state, church and school in society}

Schools, and the broader educational activities in any society, do not function in isolation from other societal structures such as the family, state and church. If we depart from a reformational Christian perspective on society, each of the societal structures such as the above-mentioned ones, are perceived to have a unique function in society which no other can fulfil and therefore it is the task of each societal structure to fulfil its unique God-given function in creation. 
Each societal structure thus has an own character and terrain which sets it apart from any other, and has persons in positions of authority to promote the function for which it is set apart. The ordinances of the Creator for his creation gives to all societal structures (church, state, school, etc.) their distinctive character and function and assigns to each its distinctive authority. As societal structures are not totally isolated from one another it is also important to take note of the interrelationships, preconditions and contexts of the unity in diversity of structures in society. The Christian reformational paradigm stands for a healthy distribution of power among the diversity of societal institutions with each exercising the required power to fulfil its own mandate (Fowler et al., 1990:81-138; Fowler, 1987:92; Van Niekerk, 2002:156). However, the brokenness of the dispensation after the fall will be manifested in society also in the distortion of the relationships between societal structures and in their malfunctioning, and therefore it is beneficial to investigate the present situation in Africa regarding the role of the church in education against this background. The church will therefore also need to be cautious of the way it involves itself in such matters as formal schooling which, strictly speaking, falls outside its terrain. It is therefore necessary to also investigate the roles and functions of other societal structures (such as the state and school) in order to clearly demarcate the church's function in relation to those of other societal structures.

The state's function is juridical in nature. The state has to harmonise the multiple juridical interests of individuals as well as societal structures in society (Smith, 1988:177; Strauss, 1978:210-214). The state is thus responsible for protecting the juridical interests of the citizens and societal structures. From this perspective on the function of the state as a societal structure, the state (as one of the societal structures) should not misuse its power, but use it in upholding a just societal dispensation. Because each societal structure is irreducible to any other and each has its own place and purpose within the fullness of human existence, the school, church and state are thus apart. The state is a political organisation and its purpose is juridical, as pointed out, and it should thus maintain fair and just juridical relations between individuals, communities and organisations within the state. The present democratic state has, however, spread its power over all terrains of society and has also usurped for itself the right to interfere with the internal working of other structures in society, such as the functioning of the school. From a reformational Christian perspective it does not have this right. The claim that the state is the highest social authority is false because all 
authority is qualified authority from a reformational perspective. A society is thus only free if each social organisation/structure is able to fulfil its particular calling. The state thus, for example, does not have the right to prescribe or interfere with the ethos and religious direction of the school as a societal structure, but it has the right to demand accountability that the resources provided by the state have been utilised responsibly (Fowler et al., 1990:81-138; Schoeman, 1988:130; Liebenberg, 2002:119-122). It is clear that the church should be wary in it's positioning vis a vis the state in involving itself in educational matters, given the inclination of the state to involve itself in the internal working of other societal structures, such as the school. The church should also be wary because the state has in the history of Western education proven itself to be a secularising influence (Holmes, 1962:13; Fowler et al., 1990:81-138).

It is worthwhile mentioning at this stage that many African states find it very difficult, if not impossible, to provide in the educational expectations of the populace, as will be pointed out in this article. The massification of African education has largely followed the Western industrial model with the state in the forefront of the provision of mass education to the populace. Unfortunately, the educational ideals of many Africans remain frustrated because of the state's inability to deliver what it set out to do regarding the massification of education. The question then arises what contribution can be made by other societal structures, such as the church, in the provision of education.

From a reformational point of view the essence of the church as a societal institution is tied to its role of preaching the Word of God, serving the sacraments and disciplining members who deviate from Biblical prescriptions (Calvyn, 1992:1265-1267, 1302-1303; Strauss, 2002:91-95; Smith, 1988:174). The church thus has a specific function in the world, and should not be distracted from its calling by taking over the roles of other societal structures or aligning itself to a state that promotes secularism or any anti-Christian ideology in education.

The Christian church is a societal structure, and as such it is deeply involved in the problems faced by contemporary Africa (Strauss, 2002:89). It is an institution in the world and therefore cannot isolate itself from other institutions and the surrounding world. It cannot distance itself from the practical application of the Christian message for cultural development and the handling of everyday circumstances and situations in the world. Christ, the head of the church, is 
the perfect example of One who was moved by both the spiritual and bodily needs of people.

The church also has a prophetic task of preaching the Word of God to its members and to the world; the priestly task of assisting its members and the community where there is need, and in Africa there is lots of need; and a "kingly" redeeming task of fighting sin in the world. The church makes its influence felt in the world inter alia through believers enacting these three offices of prophet, priest and king. Therefore, the church needs to equip believers for these tasks. The church as the body of Christ in this world is thus directly drawn into the day to day lives of its members and the communities to which they belong. This does, however, not mean that the church must interfere in the function of other societal institutions.

One would from a reformational Christian perspective be wary when trying to argue that the church be involved in educational activities such as erecting schools and educating the broader community on HIV and AIDS and leadership. This should not distract the church from its calling, and should first and foremost be seen as a temporary measure undertaken because of specific circumstances necessitating action. The authors argue that such circumstances are presently prevalent in Africa. The church is called through its members' execution of their office of priest, prophet and king to exert its influence in the world. It should be primarily through this avenue that all societal structures (such as schools) be aligned to God's Word (Schoeman, 1988:130). Church involvement should thus be preferably an indirect involvement through its members' execution of their Christian calling in the broader society.

Unfortunately the dire educational circumstances in Africa require rethinking the issue of direct church involvement in other societal structures, such as formal education. The priestly calling of the church demands closer and more direct involvement (Strauss, 2002:105-106), which can also be applied to education in Africa, specifically regarding assistance in providing schooling, education of the populace on HIV and AIDS, and training leaders for all structures of society. The nature of this involvement should, however, be qualified, as has been hinted to already, and will be elaborated on further in paragraph 4.

The role of the church in education in Africa will be placed in perspective in the following section through a discussion of the education challenge in Africa, the HIV and AIDS challenge in Africa and the leadership challenge in Africa. 


\section{Three challenges for the church in Africa}

\subsection{The formal education challenge in Africa}

At the turn of the century the Ministers of Education of African Member States (MINEDAF) admitted that the education situation in Africa is in crisis and that something has to be done, to "... wage the education battle effectively in view of its extreme urgency in Africa" (Staff reporter, 2004:1; Morris \& Lewis, 2003:3). Only a few issues of the formal education challenge are addressed in this paragraph.

Primary school completion in Africa as a whole was less than $50 \%$ at the turn of the century (Unesco, 2002:2). The Association for the Development of Education in Africa's (ADEA) newsletter (2004: 12) reports that in Africa only one child in five completes junior secondary school. The gross enrolment rates (GERs) for secondary education for developing countries is only $57 \%$ while in countries such as North America and Western Europe the GERs exceed 100\% (ADEA, 2004:12). Of the 90 million children of secondary school age in Africa, only 23 million are in school (ADEA, 2004:12). Even in 2002, fewer than sixteen countries achieved an enrolment figure of $100 \%$ in primary education. About sixteen countries achieved an enrolment figure of $70 \%$, but still have illiteracy rates of between $37 \%$ and $82 \%$, which is unacceptably high (Unesco, 2002:3). The rest of the countries in Africa have achieved less than a $70 \%$ gross enrolment, the rate being between $31 \%$ and $67 \%$ with a mean of $53 \%$. The illiteracy rate of these countries is between $16 \%$ and $76 \%$ and in the Sub-Saharan Africa region there was an increase of nineteen million illiterates the last few years alone (Unesco, 2008:34). According to Unesco (2002:3) a complete paradigm shift in education is necessary in this last category of countries.

Children between the ages nine to fifteen years appear to be causing the main problems in education, because their needs are not met. The needs of these children must be addressed in specific and appropriate ways. One reason why their needs are not met is the learner/teacher ratio. According to Salmi (2002:20), the pupil/teacher ratio in primary education in Senegal is 56 pupils for each teacher. In South Africa the situation is not much different in vast areas of the country and according to Morrow (2005:1) the South African education system is under-producing 16500 teachers a year. The training of teachers must be improved and speeded up in many African countries so that they will be able to face the additional demands and challenges coming their way. More emphasis needs 
to be placed on psychological and social needs of learners in addition to their learning needs (Serpell, 2003:1).

Another issue that needs to be addressed is the wrecked and looted educational facilities that need to be restored and restocked in large parts of Africa (Serpell, 2003:10). The training and education of disabled children and the so-called "children soldiers" must receive priority and will require time and finances, which are limited (Unesco, 2002:4). This poses a huge challenge for Africa that will be difficult to tackle alone. A team effort is needed for a solution.

According to Salmi (2002:20) there are also other important issues facing education in Africa. In a world where change is ongoing, economies are driven by knowledge (education), and global integration is increasing. Only education can make a difference to the welfare of nations. Apart from "old" problems such as access, equity and quality for all, the need for more autonomous governance and more professional management/leadership are additional real issues that need to be addressed.

There is also great concern regarding the so-called "brain drain" in Africa (Anon., 2003b:8), which effects universities' ability to respond effectively to the training needs of students, as university courses are directly affected by a loss of lecturers. It is important that leaders be retained to drive the process of development in Africa. Therefore the higher education sector is important. Lungwanga (quoted in Serpell, 2003:1) contends that higher education should

... respond to society's pressing problems of development ... including agricultural productivity ... universalisation of quality basic education ... and the management of effects ... such as poverty, disease, and destitution.

The education of girls is another problem area. In 2001, girls accounted for some $45 \%$ of primary school pupils. The Unesco report on literacy (Unesco, 2008:14) indicates that there are 35 countries in the world that contain $85 \%$ of the world's non-literate population and two-thirds of these are women and girls. The main reason for this is that according to tradition and culture, it is expected that girls must stay home and look after the household instead of obtaining an education. This forms part of a bigger issue which the former president Mbeki addressed in his opening speech at NEPAD on 22 October 2004, when he pointed out that there is no "woman movement" that can improve their status (SABC 3, 2004). 
One can conclude that formal education in Africa is in dire need of improvement. The Christian churches in Africa need to reflect on their responsibility to do more than their present efforts to alleviate the formal educational needs of not only their members, but also those of the broader society. It is outside the scope of this article to present what the church is already doing on a practical level to alleviate circumstances in formal education. Thus the following are mere examples of what can be done without the church moving outside the bounds of its own societal institutional calling.

- The church needs to fulfil its prophetic function by pointing out, according to the Word of God, where other societal institutions neglect their educational responsibilities, and in this regard encourage its members to establish their own independent Christian schools.

- The church needs to fulfil its priestly function in various ways, inter alia by making its facilities available for educational purposes (e.g. for nursery schools and basic literacy training), involving its members in school feeding schemes and assisting orphaned children to obtain and continue schooling.

- The church needs to fulfil its kingly function, inter alia by working with the Christian parent community against secularising influences in education, and promoting a Christian ethos in the state schooling system.

The authors believe that the Christian church should only in exceptional circumstances be directly involved in the establishment and control of Christian private schools, and then only until Christian parent communities can take over the control of these schools. The church should avoid establishing schools together with the state, as the state has in the history of modern education proved that it exerts a secularising influence rather than a Christianising influence in education (see paragraph 2).

\subsection{The challenge of HIV and AIDS in Africa}

In Africa, which has some of the poorest countries in the world, the impact of the AIDS virus has been the most severe. There are now an estimated 22 million people in Africa living with HIV and AIDS (Avert.org, 2009c:1). In 2007 1,7 million people alone were infected in the Sub-Saharan region, in comparison with Asia which has an estimate figure of about five million people living with HIV and AIDS (Avert.org, 2009b:1-2; cf. also UNAIDS, 2007:7). Closer to home, the Actuarial Society of South Africa's (ASSA) provincial model 
(ASSA, quoted in Avert.org, 2009a:4) calculates that 345640 people died because of AIDS in 2006 in South Africa (which has the largest number of people infected with HIV in the world (UNAIDS, 2007:16), while 350000 were claimed by AIDS in 2007. According to the ASSA 2003-model about 5,4 million people will have died of AIDS in South Africa by 2015 and there are more than eleven million orphans in the Sub-Saharan region (Avert.org, 2009c:1). In the SubSaharan region about 1,6 million people died of AIDS in 2007 (UNAIDS, 2007:7). These figures alone point towards a huge educational task on the prevention of HIV and AIDS.

The combination of HIV and AIDS and economic migration in Southern Africa is causing serious human resources depletion (Morris \& Lewis, 2003:8). Because of the HIV and AIDS pandemic, the life expectancy in most African nations dropped from 60 years to about 35-40 in 2007 (Avert.org, 2009a:1). In South Africa the life expectancy has dropped from 68.5 years before AIDS, to 48 years in 2005 and in 2015 it could be 36,5 years (Avert.org, 2005:7).

It is important to take note of the major impact HIV and AIDS have on education because of the loss of teachers and the great number of orphans in Africa (Unesco, 2002:2). The HIV and AIDS pandemic and other problems are endangering development and can reverse positive trends in the development of education (Unesco, 2002:3). According to a report in Beeld (Anon., 2004:11) about 1200 teachers die every year in Malawi alone. A Zimbabwean minister of education and sport in a speech referred to HIV and AIDS as the leading factor in the loss of educational personnel, and a high dependency ratio, because of the increase in the number of orphans (Unesco, 2002:6). A report in the Times of Zambia (Anon., 2003a:4) stated that more teachers are dying of AIDS in Zambia than can be replaced by the training of new teachers. Even in South Africa HIV and AIDS are having a devastating effect on the supply of teachers. Hall (2003:42) does not mince with words in his description of the situation in South Africa:

There is no doubt that the teaching profession is facing a crisis in the supply of a sufficient number of newly qualified teachers required to replace the normal resignations, retirements and the approximately 50000 teachers who will die between 2001 and 2010 from Aids-related causes.

According to Beeld (Anon., 2005:4), 23500 teachers in South Africa have the AIDS virus and most of them do not even know it. Morris 
and Lewis (2003:26), UN-envoys, drew the following conclusion in their mission report on Zambia:

The combination of economic migration and HIV and AIDS has taken a devastating toll on the human resources capacity within the Government and society. The agriculture, health and educational sectors have been particularly affected ...

If more people such as teachers, politicians and businessmen are dying of HIV and AIDS or related sicknesses, the less educated people will have to run and develop their countries, affecting the quality of life.

The effect of HIV and AIDS on poorer households is more devastating because if a breadwinner dies, more children (especially girls) are removed from school to help earning money in various ways, even prostitution (cf. Avert.org, 2005:3). With regard to the plight of women the UN special envoys (Morris \& Lewis, 2003:4) report as follows:

... very little is being done to reduce women's risks, to protect them from sexual aggression and violence, to ease their burdens or to support their coping and caring efforts. The apparent lack of urgency, leadership, and responsibility in response to the pandemic's effects on women and girls is deeply troubling.

Spending on HIV and AIDS still falls short of what is required (Avert.org, 2009b:7). An estimated 22,1 billion dollars were needed in 2008, increasing each year. It is clear from the above that apart from the finances needed, there is also an educational task with regards to protecting the most vulnerable people in society.

According to Avert.org (2009c:2-3), the AIDS pandemic is having a widespread impact on inter alia the following:

- Erasing decades of progress made in extending life expectancy

- Families, who are losing their income earners, leaving behind orphans

- Strain on finances and the health sector

- Schools are heavily affected by HIV and AIDS

- Labour is affected and economic activity and social progress is hampered 
- A brake is put on economic growth and development.

It is clear that the impact of HIV and AIDS in Africa is such that the church needs to reflect seriously on its contribution towards alleviating such an impact. The argument in this article is that the church also has a specific educational task relating to the HIV and AIDS pandemic. On a practical level the authors would suggest the church should do the following:

- The church needs to fulfil its prophetic function by inter alia providing training from a Christian perspective to its members and the community on combating the HIV and AIDS pandemic.

- The church needs to fulfil its priestly function in various ways, inter alia by making its facilities available for HIV and AIDS training and supporting those suffering because of the pandemic, such as the many orphans.

- It needs to fulfil its kingly function inter alia by working actively against sin associated with the pandemic and manifesting because of the pandemic.

\subsection{The leadership challenge in Africa}

According to Rotberg (2004:1), most leaders in Africa use power as an end in itself and are unswayed by reason. Africans also content that leadership in Africa is a problematic issue (Van Rensburg, 2007:xi). Adeyemo (quoted in Heidebrecht, 2006:1; Van der Walt, 1995), retired general secretary of the Association of Evangelicals in Africa, is quite adamant when he declares that Africa's political and economical troubles can be traced to the failure of leadership: "... for decades Africa has had bosses, not leaders". Abdulai (2007:2) blames the existing misery of poverty in Africa on the "... unwillingness of African leaders to rise up to the challenge of leadership - which is to serve and to serve unreservingly". This is in line with the contention of Carolus (2003:16) who argues that leadership starts:

... on the inside with a transformation of the heart and then moves outwards to serve others ... ultimately it is the quality and spirit of prevailing leadership that will shape the future of nations. This leadership is a state of mind, a result of determination ... a commitment to excellence, a harnessing of energy ...

Also on the website of the African Leadership Initiative (ALI) it is stated that there is a crisis of leadership in Africa which can be seen 
in the continued poverty for millions of people. One of the main reasons for this state of affairs is the lack of a broadly shared vision for the future. It is contended that after decades of "command and control" policies, government leaders still do not have a clear understanding of the changes required in their roles and behaviour. The ALI believes progress is dependent on the next generation of leaders in all sectors coming together to identify and address their personal strengths and weaknesses as leaders, understanding the challenges they face, sharing and refining their respective visions and leading by example. In line with this Van Rensburg (2007:xi) sees the challenge of African leadership as one where Africans themselves build a better future with strong leadership that is congruent with the unique quality and strengths of the African culture and which is focused on unlocking potential and serving others.

Although some leaders may be "born leaders" there are many people who believe leadership must and can be learned (Maxwell, 2008:33). According to Serpell (2003:1), in the past very few individuals were trained in leadership, and those who underwent training locally or abroad, received education only in general terms. This led to inefficiencies and poor performance. Serpell (2003:1) argues that one of the major challenges facing education is leadership training, because managers or leaders at all levels need training in various skills, both technical and social.

One of the consequences of the African crisis situation is an increase in the number of displaced persons or refugees (Staff reporter, 2004:4). In this regard it can be pointed out that more than 300000 people were killed and about two million people were displaced in Sudan alone (Hoganson, 2006:1). This factor together with the effect of the AIDS pandemic (cf. previous paragraph) are generally draining the number of leaders and potential leaders and causing a leadership crisis in Africa. Added to this issue is the concern that the programmes for training people, and specifically leaders, are not meeting required standards for equipping them to address the crises such as those discussed in this article (Serpell, 2003:1). Leaders are not prepared and equipped adequately to change their way of thinking. A paradigm shift is required (Gustafson, 2002:5), so that they will be able to face these challenges and find appropriate solutions. Leaders should possess more and better skills than leaders of the past, simply because leaders today need to fulfil more roles, and find more and better solutions for the various problems facing them. 
It is clear from the above that the church cannot shy away from the leadership challenges in Africa; it needs to contribute towards meaningful solutions. The church will have to face the challenge of how persons and leaders should be identified and trained (or existing leaders retrained) as leaders in its own ranks, and in the broader community. According to Reeder $(2008: 11,15,18)$ the church needs to prioritise developing and deploying leaders who have been mentored in the church and can then be sent out to impact positively on the world. He argues that the church must turn away from the worldly, corporate style of leadership and return to the Biblical definition and method of producing leaders for the church and the world. In this regard the church must foster desirable leadership by imparting Christian attitudes and values and thus building character.

Leadership as a theme for academic research has gained considerable prominence during the past decades (Banks \& Ledbetter, 2004:11-24; Mentz, 2003:3-4), and the increasing volume of Christian literature on leadership provides an excellent tool for the development of leadership courses for the church to train its own leaders, and to develop leaders for the wider community. The training of a Christian leadership cadre among church members should be regarded as an investment in future cultural development as discussed in paragraph 4 . The church is in the favourable position that it can provide leadership opportunities to its members within the local and wider church environment to develop their own leadership qualities - qualities that can be well utilised also in the wider community. The Christian churches in Africa can make a considerable contribution to the leadership crisis in Africa by expanding their vision on leadership training not only for their own members, but also moving into the community to promote a Christian vision for the future of society by means of leadership training.

\section{The formative socio-cultural calling of the church}

Having presented information on the formal education crisis, the HIV and AIDS crisis and the leadership crisis in Africa in the previous paragraphs, the fundamental reflection on church involvement in education, which started in paragraph 2, is extended in this paragraph, incorporating also an historical educational perspective into this fundamental reflection.

The central and radical Biblical theme of creation, fall into sin and redemption by Christ is the central spiritual Leitmotif behind all Christian thought, which should inspire Christians and the church in such a way that the church becomes a formative socio-cultural 
power and a formative factor in human cultural development. In spite of the fallible and imperfect character of Christians as human beings, and the church as a societal institution, their calling remains one of promoting the Kingdom of God on earth. Despite not being able to live up to the normative implications of the radical Biblical ground motive for cultural formation, this calling cannot be forsaken or neglected. From a Christian perspective the historical development of humanity entails the development of its formative power over the world and over societal life (Dooyeweerd, 1968:33-34, 42, 91-92, 98-105, 132; Kalsbeeck, 1975:63-66).

The church has a definite formative socio-cultural calling in the world in line with its prophetic, priestly and kingly tasks (cf. par. 2); it thus needs to make its influence felt in the world in relation to other societal institutions and the community in general through its own and its individual members' Christian testimonies in the world. Christianity in Africa must, therefore, assume a socio-cultural form so that it may be a formative power in African society and in African societal institutions, such as schools, the state, industrial communities, et cetera. It is of paramount importance that African society be saturated with a Biblical life and worldview in order to take part in responsible and accountable Christian cultural development. This is a very important supportive educational task of the church in order to enable its members to expand their cultural development calling (Gen. 1:28). It is indeed in order for the church to move outside its own membership to assist in providing the best possible Christian education for all people in order to develop a Christian civilisation and assist in the development of the inherent cultural development potential in creation. After all, the laws and ordinances given by the Creator for his creation apply to all people. Christian churches in Africa need to consider whether they are doing enough to assist formal education as well as education on HIV and AIDS and leadership in order to promote the process of Christian cultural development. An indication of the church's calling to involve itself in formal education can be found in the Western history of education.

During the Reformation the reformers, and notably also Martin Luther and John Calvin, wanted to expand formal education to the whole population. During the preceding Middle Ages the Roman Catholic Church had a monopoly on education, which was restricted to very few of the population. The Protestant Reformation introduced a new basis for elementary vernacular education, namely the need for a personal study of the Bible in order to ensure salvation, as the vernacular Bible was considered fundamental and necessary to 
assist believers in their faith. The Reformation in conjunction with the state was remarkably successful in broadening the basis of elementary education (Parker, 1970:33-38; Brubacher, 1966:365-366).

Christianity also hugely contributed towards scientific developments in this period. The preconditions about physical reality on which modern science, especially natural science, could be built, was grounded in a Biblical view of reality. Thus Christianity in general, and not only the Reformation, was responsible for laying the foundations on which modern science was built in the time of the Reformation. These preconditions were thus the foundation upon which modern Western culture and the modern systems of general education for the masses could be developed, and they also supported political, economic and social changes in the West leading to the further massification of education later on. These preconditions supported by Christian belief, are inter alia, that an ordered reality was created which the human brain can know and understand, that God does not form a part of creation, but is separate thereof as its Creator and Sustainer, and that time follows a linear progression from the beginning to the God-ordained end (Hooykaas, 1972:9; Ouweneel, 1997:48-52; Van Niekerk, 1999). Notably traditional African religion and culture do not support these preconditions; so there is work for the church to saturate not only African Christianity, but also the broader community with the Christian view of reality. If this is not done, there is less hope that Africa will be able to sustain the modern systems of education that it has inherited from the missionary and colonial endeavours in Africa, and has built up since independence.

Taking the above historical account into consideration, the task of the church with regard to formal education would be, firstly, to encourage Christian parent communities to establish Christian schools, especially in places where there are no schools, and to assist them as far as possible in doing this; and secondly, to assist Christian parent communities to provide literacy training opportunities for illiterate adults in their communities. The latter would be in line with and an extension of the Protestant Reformation's ideal of enabling all people to be able to read the Bible. It will also provide a basis for development in communities where literacy is a problem. Literacy will enable Africans to learn the basic Biblical principles that will assist their cultural development and those of their generations to come. The good deeds of the church and its members in the field of formal education, HIV and AIDS and leadership education, as dis- 
cussed earlier in paragraph 3 , will make a further contribution towards Christian cultural development.

The above exposition is in line with the statement quoted in the Introduction (Commission for Africa, 2006:15) by the Evangelical Christian Community in Africa: "The church has a big role to play in bringing about the social changes which in turn can enable development."

\section{Conclusion}

The purpose of this article was to reflect on the involvement of the church in education in Africa on the basis of a fundamental analysis of the role of the church in education. This reflection should also be related to the situation prevailing in Africa at the beginning of the 21st century, which is presented in this article in relation to the formal education crisis, the HIV and AIDS crisis and the leadership crisis in Africa. The brief analysis undertaken to highlight the formal schooling, AIDS and leadership crises in Africa points towards the need for deeper involvement by the church in formal education, HIV and AIDS education and leadership education. A fundamental analysis of the role of the church in education also points towards a justification for such involvement.

\section{List of references}

ABDULAI, D.N. 2007. A call to African leadership in turbulent times. http://www.sblunisa.ac.za/content.php?section=28\&article Date of access: 25 Mar. 2009.

ADEA

see ASSOCIATION FOR THE DEVELOPMENT OF EDUCATION IN AFRICA

AFRICAN LEADERSHIP INITIATIVE. http://www.africaleadership.net/about/ overview.htm Date of access: 25 Mar. 2009.

ANON. 2003a. Aids orphans fuel Africa's wars. Times of Zambia: 4, 24 Sept.

ANON. 2003b. Breinkwyn belemmer VN-hulp. Beeld: 8, 30 Jul.

ANON. 2004. Afrika. Beeld: 11, 16 Jan.

ANON. 2005. 10,000 onnies kort vigshulp. Beeld: 4, 15 Oct.

ASSOCIATION FOR THE DEVELOPMENT OF EDUCATION IN AFRICA. 2004. Secondary education: the missing link. Association for the Development of Education in Africa newsletter, 16(3):1-23.

AVERT.ORG. 2005. The impact of AIDS in Africa. http://www.avert.org/ aidsimpact.htm Date of access: 20 Sept. 2007.

AVERT.ORG. 2009a. South Africa HIV and AIDS statistics. http://www.avert. org/safricastats.htm Date of access: 18 Apr. 2009. 
AVERT.ORG. 2009b. HIV and AIDS in Africa questions and answers. http://www.avert.org/aids-africaquestions.htm Date of access: 20 Apr. 2009.

AVERT.ORG. 2009c. HIV and AIDS in Africa. http://www.avert.org/aafrica.htm Date of access: 20 Apr. 2009.

BANKS, R. \& LEDBETTER, B.M. 2004. Reviewing leadership: a Christian evaluation of current approaches. Grand Rapids: Baker.

BRUBACHER, J.S. 1966. A history of the problems of education. New York: McGraw-Hill.

CALVYN, J. 1992. Institusie van die Christelike Godsdiens. Boek 4. Vertaal deur H.W. Simpson. Potchefstroom: Calvyn Jubileumboekefonds.

CAROLUS, C. 2003. Leadership in practice. Forum, 13(2):16-17.

COMMISSION FOR AFRICA. 2006. Submission to the commission for Africa from members of the Evangelical Christian Community in Africa facilitated by Tearfund. http://www.Tilz.tearfund.org/Research/ Commission+for+Africa.html Date of access: 20 Sept. 2007.

DOOYEWEERD, H. 1963. Vernieuwing en bezinning om het reformatorisch grondmotief. Zutphen: Van den Brink.

DOOYEWEERD, H. 1968. In the twighlight of Western thought. Nutley: Craig.

DOOYEWEERD, H. 1979. Roots of Western culture: pagan, secular and Christian options. Toronto: Wedge.

FOWLER, S. 1987. Christian educational distinctives. Potchefstroom: PU for CHE.

FOWLER, S., VAN BRUMMELEN, H. \& VAN DYK, J. 1990. Christian schooling: education for freedom. Potchefstroom: Potchefstroom University Press.

GUSTAFSSON, I. 2002. Sector-wide approaches: towards a comprehensive, integrated vision of development. Association for the Development of Education in Africa newsletter,14(4):3-5.

HALL, G. 2003. The impact of the AIDS pandemic on teacher supply and demand in South Africa. (In Education Africa Forum. 6th ed. Gauteng. p. 34-45.)

HEIDEBRECHT, P. 2006. African church leaders speak to the World Bank. http://www.clafrica.com/articles/books.htm Date of access: 20 Sept. 2007.

HOGANSON, R. 2006. Sanctus real partners with African leadership. http://www.1cubed.com/display.php?id=858\&sectionID=29 Date of access: 20 Apr. 2009.

HOLMES, H. 1962. Religious education in the state school: a South African study. Johannesburg: Nelson.

HOOYKAAS, R. 1972. Religion and the rise of modern science. Grand Rapids: Eerdmans.

KALSBEECK, L. 1975. Contours of a Christian philosophy. Toronto: Wedge.

LIEBENBERG, P.W. 2002. Staatkundig. (In Van Niekerk, E.J. \& Hayes H.J., red. Reformerend die millennium in: ons Calvinistiese erfenis en roeping. Bloemfontein: VCHO. p. 109-140.)

MAARTHAI, W. 2009. The challenge for Africa: a new vision. London: Heinemann.

MAXWELL, J.C. 2008. Beproefde beginsels vir leiers. Kaapstad: Struik.

MENTZ, P.J. 2003. Van bestuur na leiding. Potchefstroom: PU vir CHO. (Wetenskaplike bydraes, Reeks H: Inougurele Rede, nr. 178.)

MORRIS, J.T. \& LEWIS, S. 2003. United Nations mission report: Lesotho, Malawi, Zambia and Zimbabwe. Rome. 
MORROW, W. 2005. A shrinking pool. Mail \& guardian online: Printer version. http://www.mg.co.za/printPage.aspx?area=/the_teacher/teacher_features? \&atricles=2 Date of access: 30 Apr. 2007.

OUWENEEL, W.J. 1997. Wijs met de wetenschap. Heerenveen: Barnabas.

PARKER, S.C. 1970. The history of modern elementary education. Totowa: Littlefield \& Adams.

REEDER, H.L. 2008. The leadership dynamic: a Biblical model for raising effective leaders. Wheaton: Crossway.

ROTBERG, R.I. 2004. Strengthening African leadership in Foreign Affairs. http://www.foreignaffairs.com Date of access: 20 Apr. 2009.

SABC 3. 2004. News bulletin on 22 October at 19:00.

SALMI, J. 2002. Constructing knowledge societies: new challenges for tertiary education. Association for the Development of Education in Africa newsletter, 14(4):20-21.

SCHOEMAN, P.G. 1988. Wysgerige pedagogiek. Pretoria: Sacum.

SERPELL, R. 2003. Speech at the official opening of the Educational Management Training for Education Managers, University of Zambia.

SIFUNA, D.N. 1990. Development of education in Africa: the Kenyan experience. Nairobi: Initiative Publishers.

SMITH, H.J. 1988. Sosiologie vir die Ryksburger - 'n kennismaking. Bloemfontein: VCHO.

STAFF REPORTER. 2004. Zambia feels the pain of the "brain drain". www.africaonline.com/site/articles/1,3,49924.html Date of access: 19 Sept. 2006.

STRAUSS, D.F.M. 1978. Inleiding tot die kosmologie. Bloemfontein: Sacum.

STRAUSS, S.A. 2002. Kerklik. (In Van Niekerk, E.J. \& Hayes H.J., red. Reformerend die millennium in: ons Calvinistiese erfenis en roeping. Bloemfontein: VCHO. p. 87-107.)

UNAIDS see UNITED NATIONS AIDS

UNESCO. 2002. Report: Tanzania calling - taking up the challenge of education in Africa. Conference on education. Dakar. http://www.sadtu. org.za/ev/nov_dec_2002/tanzania.html Date of access: 20 Sept. 2007.

UNESCO. 2008. Institute for Statistics: Literacy report.

UNITED NATIONS AIDS. 2007. Aids epidemic update. http://www.unaids.org Date of access: 20 Apr. 2009.

VAN DER WALT, B.J. 1995. Leaders with vision: how Christian leadership can tackle the African crisis. Potchefstroom: $\mathrm{PU}$ vir $\mathrm{CHO}$.

VAN NIEKERK, E.J. 1999. Conflicting belief systems: some implications for education. Koers, 64(1):1-18.

VAN NIEKERK, E.J. 2002. Onderwys. (In Van Niekerk, E.J. \& Hayes H.J., red. Reformerend die millennium in: ons Calvinistiese erfenis en roeping. Bloemfontein: VCHO. p. 141-164.)

VAN RENSBURG, G. 2007. The leadership challenge in Africa: a framework for African Renaissance leaders. Pretoria: Van Schaik. 


\section{Key concepts:}

church and African education

education: HIV and AIDS

education: leadership

formal education in Africa

Kernbegrippe:

formele onderwys in Afrika

kerk en onderwys in Afrika

leierskapsopleiding

opvoeding: HIV en VIGS 
